\title{
Agar in the management of hyperbilirubinaemia in the premature baby
}

\author{
C. ROMAGNOLI, G. POLIDORI, M. FOSCHINI, L. CATALDI, P. DE TURRIS, \\ G. TORTOROLO, and R. MASTRANGELO \\ From Clinica Pediatrica, Università Cattolica del S. Cuore, Roma, Italy
}

\begin{abstract}
Romagnoli, C., Polidori, G., Foschini, M., Cataldi, L., De Turris, P., Tortorolo, G., and Mastrangelo, R. (1975). Archives of Disease in Childhood, 50, 202. Agar in the management of hyperbilirubinaemia in the premature baby. Eighty low birthweight infants ( 1500 to $2500 \mathrm{~g}$ ) were randomly assigned to a group given oral agar and a control group. The study was first performed in 24 agar-fed babies and 24 control babies. The treated infants received a daily total amount of $600 \mathrm{mg} / \mathrm{kg}$ of agar beginning at 12 hours of age, for 7 days. In the later stage of the trial, 16 agar-fed babies and 16 control babies were investigated. The total daily amount of agar was raised to $700 \mathrm{mg} / \mathrm{kg}$, beginning at 6 hours of age for 7 days.

No complications were observed with the administration of agar. Serum bilirubin levels were not significantly lower in the agar-fed infants. We conclude that agar supplemented feeding is not indicated in the management of hyperbilirubinaemia in low birthweight newborn infants.
\end{abstract}

Phototherapy is highly effective in both prevention and treatment of neonatal hyperbilirubinaemia. Serious untoward reactions have not been reported, although the possibility of such toxicity cannot be excluded at the present time (Behrman et al., 1974). An alternative approach has been suggested by recent work (Poland and Odell, 1971), showing that lower levels of serum bilirubin occur in agar-fed term infants with 'physiological' hyperbilirubinaemia. The purpose of this communication is to report our experience with agar in the control of neonatal hyperbilirubinaemia in premature infants.

\section{Methods}

80 low birthweight infants (1500 to $2500 \mathrm{~g}$ ) were randomly assigned to a therapy group and to a control group. The study was performed first in 24 agar-fed babies and in 24 control babies. The treated infants received a daily total amount of $600 \mathrm{ng} / \mathrm{kg}$ agar* beginning at 12 hours of age and continuing for 7 days. Later in the trial, 16 agar-fed babies and 16 control babies were investigated and the total daily amount of agar was raised to $700 \mathrm{mg} / \mathrm{kg}$, beginning at 6 hours of age and continuing for 7 days.

Infants in each group were similar with respect to mean birthweight, gestational age, and sex (Table).

Received 29 July 1974.

*Agar U.S.P. Lot no. N.C. 710542. Amend Drug and Chemical Co. Inc., New York.
TABLE

Clinical characteristics of study groups

\begin{tabular}{|c|c|c|c|c|}
\hline Group & $\begin{array}{l}\text { No. of } \\
\text { infants }\end{array}$ & $\begin{array}{c}\text { Sex ratio } \\
(M: F)\end{array}$ & $\begin{array}{c}\text { Birthweight } \\
(\mathbf{g}) \\
(\text { mean } \pm \text { SE) }\end{array}$ & $\begin{array}{c}\text { Gestional } \\
\text { age }(w) \\
(\text { mean } \pm S E)\end{array}$ \\
\hline $\begin{array}{l}\text { First study gr } \\
\text { Agar-fed } \\
\text { Controls }\end{array}$ & $\begin{array}{l}\text { up } \\
24 \\
24\end{array}$ & $\begin{array}{l}11: 13 \\
11: 13\end{array}$ & $\begin{array}{l}2240 \pm 40 \cdot 1 \\
2118 \pm 52 \cdot 0\end{array}$ & $\begin{array}{l}35 \cdot 09 \pm 0.60 \\
35 \cdot 31 \pm 0.50\end{array}$ \\
\hline $\mathbf{P}$ & & & $>0.05$ & $>0.05$ \\
\hline $\begin{array}{l}\text { Second study } \\
\text { Agar-fed } \\
\text { Controls }\end{array}$ & $\begin{array}{r}\text { roup } \\
16 \\
16\end{array}$ & $\begin{array}{l}6: 10 \\
6: 10\end{array}$ & $\begin{array}{l}2265 \pm 47 \cdot 6 \\
2180 \pm 60 \cdot 0\end{array}$ & $\begin{array}{l}35 \cdot 78 \pm 0.80 \\
35 \cdot 13 \pm 0.60\end{array}$ \\
\hline $\mathbf{P}$ & & & $>0.05$ & $>0.05$ \\
\hline
\end{tabular}

Infants with haemolytic anaemia, respiratory distress syndrome, sepsis, or malformations were excluded from the study. Blood groups, Rh factor, Coombs's test, haemoglobin, RBC and WBC counts, haematocrit, reticulocyte count, blood glucose, serum, calcium, G6PD (Beutler test) and acid-base status were determined for each baby in the first day of life. Daily measurements of total serum bilirubin concentrations were performed between 8 and 9 a.m. for 8 days by the same technician according to the method of Malloy and Evelyn (1937). Conjugated bilirubin measurements were performed on the 3rd day of age. Daily weights and stools were recorded for each infants. All 
infants were fed.with the same formula (Similac Abbott) and received agar powder in the first $5 \mathrm{ml}$ of each formula.

\section{Results}

No complications were observed with the administration of agar. There was no significant difference in haematocrit and weight values between treated and control infants. No diarrhoea or bulky stools were noted in the agar-fed infants. Conjugated bilirubin values were all within normal limits.

In the first trial (Fig. 1), the agar-fed infants

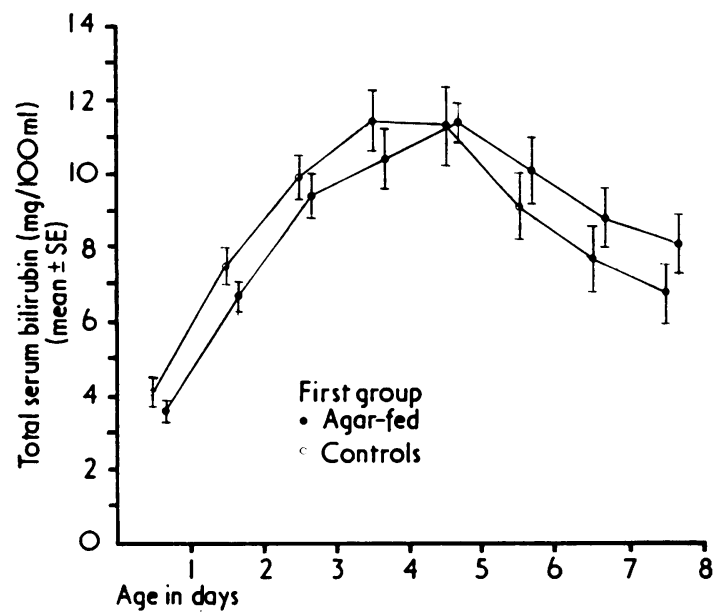

FIG. 1.-Mean total serum bilirubin concentration of first study group infants. The agar-fed infants received a daily total amount of agar of $600 \mathrm{mg} / \mathrm{kg}$, beginning at 12 hours of age for 7 days.

had a rise of mean serum bilirubin concentration from $3.6 \mathrm{mg} / 100 \mathrm{ml}(\mathrm{SE} \pm 0 \cdot 3)$ on the first day to $11.4 \mathrm{mg} / 100 \mathrm{ml}(S E \pm 0.8)$ on the 5 th day of life, whereas the serum bilirubin concentration in the control infants increased from the initial value of $4.1 \mathrm{mg} / 100 \mathrm{ml}(S E \pm 0.4)$ to a maximum of $11.4 \mathrm{mg} / 100 \mathrm{ml}(\mathrm{SE} \pm 0 \cdot 8)$ on the 4 th day of life.

In the second trial (Fig. 2) the mean serum bilirubin concentration of the agar-treated babies rose from $3.2 \mathrm{mg} / 100 \mathrm{ml}(S E \pm 0 \cdot 3)$ on the first day to $13.8 \mathrm{mg} / 100 \mathrm{ml}(\mathrm{SE} \pm 1 \cdot 0)$ on the 5 th day of life. In the control group the serum bilirubin rose from $3.7 \mathrm{mg} / 100 \mathrm{ml}(S E \pm 0 \cdot 3)$ on the first day to $12.5 \mathrm{mg} / 100 \mathrm{ml}(\mathrm{SE} \pm 1 \cdot 4)$ on the 4 th day.

No statistically significant difference was noted in the number of exchange transfusions required by the treated infants versus controls in each set of premature infants investigated: 2 versus 4 exchange transfusions in the first trial, 2 versus 5 exchange transfusions in the second trial.

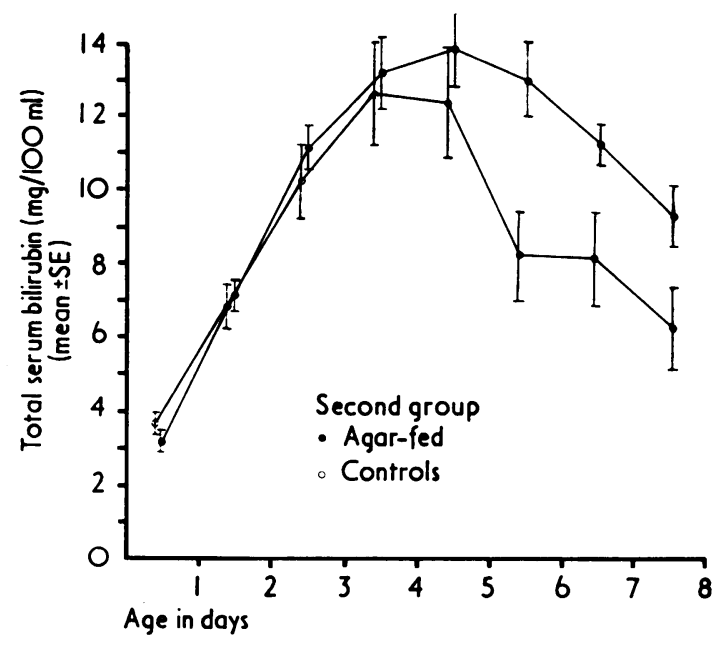

FIG. 2.-Mean total serum bilirubin concentration of second study group infants. The agar-fed infants received a daily total amount of agar of $700 \mathrm{mg} / \mathrm{kg}$, beginning at 6 hours of age for 7 days.

\section{Discussion}

The role of enterohepatic circulation of bilirubin in 'physiological' hyperbilirubinaemia has not been well established (Brodersen and Hermann, 1963; Gilbertsen, Bossenmaier and Cardinal 1962; Lester and Schmid, 1963; Ulstrom and Eisenklam, 1964), although Poland and Odell (1971) have shown that reabsorption of bilirubin from the intestine may be a major contributory factor. They reported no further rise in neonatal serum bilirubin concentrations in term infants when a formula supplemented with agar was given. At the same time an increased excretion of bilirubin in the faeces was shown. Our results failed to detect any significant serum bilirubin reduction in agar-fed low birthweight infants.

The USP agar used in these 2 studies was one of the most effective lots, and the failure of agar to reduce the degree of hyperbilirubinaemia, therefore, cannot be attributed to the reduced capacity of the specific preparation to 'sequester' bilirubin in the intestinal tract. It is possible that a dosage factor may be critical in low birthweight infants as compared to term infants. However, the higher dosage of agar attempted in the second trial of our study did not produce any significant reduction of serum bilirubin. It has been postulated that agar may also prevent reabsorption of the bilirubin within the gut at the time of birth, which can be partially responsible for 'physiological' hyperbilirubinaemia. On the basis of this assumption 


\section{Romagnoli, Polidori, Foschini, Cataldi, De Turris, Tortorolo, and Mastrangelo}

we began agar administration earlier-6 hours after birth -in the second set of low birthweight infants investigated. There was still no significant effect.

Perhaps the enterohepatic circulation of bilirubin plays no significant part in the mechansim of hyperbilirubinaemia in premature infants. In any case, we agree with Maurer et al., (1973) who had a similar experience although in a small number of cases, that agar-supplemented feeding is not indicated in the management of hyperbilirubinaemia in low birthweight newborn infants.

The authors acknowledge the assistance of the nurses of the Premature Infants Centre (head nurse, Miss G. Farnedi), the parents who made this study possible, and Dr. R. L. Poland (Detroit, Michigan) who supplied the agar.

\section{REFERENCE;}

Behrman, R. E., Brown, A. K., Currie, M. R., Hastings, J. W. Odell, G. B., Schaffer, R., Setlow, R. B., Vogl, T. P., and Wurtman, R. J. (1974). Preliminary report of the committee on phototherapy in the newborn infant. Fournal of Pediatrics, 84, 135.
Brodersen, R., and Hermann, L. S. (1963). Intestinal reabsorption of unconjugated bilirubin: a possible contributing factor in neonatal jaundice. Lancet, 1, 1242.

Gilbertsen, A. S., Bossenmaier, I., and Cardinal, R. (1962). Enterohepatic circulation of unconjugated bilirubin in man. Nature, 196, 141 .

Lester, R., and Schmid, R. (1963). Intestinal absorption of bile pigments. II. Bilirubin absorption in man. New England fournal of Medicine, 269, 178.

Malloy, H. T., and Evelyn, K. A. (1937). The determination of bilirubin with the photoelectric colorimeter. Fournal of biological Chemistry, 119, 481.

Maurer, H. M., Shumway, C. N., Draper, D. A., and Hossaini, A. A. (1973). Controlled trial comparing agar, intermittent phototherapy, and continuous phototherapy for reducing neonatal hyperbilirubinemia. Fournal of Pediatrics, 82, 73.

Poland, R. L., and Odell, G. B. (1971). Physiologic jaundice: the entero-hepatic circulation of bilirubin. New England fournal of Medicine, 284, 1.

Ulstrom, R. A., and Eisenklam, E. (1964). The enterohepatic shunting of bilirubin in the newborn infant. I. Use of oral activated charcoal to reduce normal serum bilirubin values. Fournal of Pediatrics, 65, 27.

Correspondence to Dr. C. Romagnoli, Clinica Pediatrica, Università Cattolica del S. Cuore, Largo A. Gemelli 8, 00168 Roma, Italy. 